\title{
Aflatoxigenic Contamination of Groundnut (Arachis hypogaea L.) Seed and its Management Using Seed Extract of Moringa oleifera Lam. and Rhizome of Zingiber officinale Rosc. in Katsina State, Nigeria
}

\section{Chile DD and Gwa VI*}

Department of Crop Protection, Faculty of Agriculture and Agricultural Technology, Federal University, Nigeria

*Corresponding author: Victor Gwa, Department of Crop Protection, Faculty of Agriculture and Agricultural Technology, Federal University, Dutsin-Ma, PMB 5001, Katsina State, Nigeria,

\section{Mini Review \\ Volume 4 Issue 2}

Received Date: June 07, 2021

Published Date: July 12, 2021

DOI: $10.23880 /$ oajmms-16000141 Email: igwa@fudutsinma.edu.ng; gwavictor9@gmail.com

\section{Abstract}

Studies on aflatoxin seed contamination of groundnut (Arachis hypogaea) in storage and its management using seed extract of Moringa oleifera and rhizome of Zingiber officinale was carried out on diseased seeds collected from Dutsin-Ma, Kurfi and Safana Local Government Areas of Katsina State, Nigeria between March and July, 2019. Aspergilus niger, A. flavus, A. ochraceus, A. tamari, A. parasitica, Rhizotonia spp, mucor spp and F. oxysporum were isolated. A. niger was the most frequently occurring pathogen in all the locations in March, 2019 with a range of 9 in Kurfi to 13 Dutsin-Ma and between 14 in Kurfi and 22 in Dutsin-Ma in July while the least was Mucor with a range of 3 in Dutsin-Ma and 6 in Kurfi both in July. Pathogenicity test conducted illicit rot in the healthy groundnut seeds. A. niger and A. flavus which were the most virulent pathogenic fungi responsible for aflatoxin contamination in groundnut seeds were controlled with the two extracts. Z. officinale was found to be more effective in the control of A. niger than M. oleifera at $40 \mathrm{~g} / \mathrm{L}$ with inhibition of $60.32 \%$ and at $120 \mathrm{~g} / \mathrm{L}$ with inhibition of $87.33 \%$ compared to M. oleifera which inhibited A. niger mycelial at $40 \mathrm{~g} / \mathrm{L}$ by $59.79 \%$ and at $120 \mathrm{~g} / \mathrm{L}$ by $73.53 \%$. M. oleifera however, proved more efficacious in the management of $A$. flavus than Z. oficinale at $40 \mathrm{~g} / \mathrm{L}$ and $80 \mathrm{~g} / \mathrm{L}$ with percentage growth inhibition of $60.79 \%$ and $62.47 \%$, respectively compared to a lower inhibition of $60.52 \%$ and $60.94 \%$ at $40 \mathrm{~g} / \mathrm{L}$ and $80 \mathrm{~g} / \mathrm{L}$ of Z. officinale, respectively. In both cases, the two extracts proved more effective on A. niger than A. flavus. It is therefore, recommended that extracts of $Z$. officinale and $M$. oleifera at different concentrations can be used to effectively manage rot pathogens of groundnut seeds in storage by farmers.

Keywords: Aspergillus niger; Effective; Inhibition; Pathogenicety test; Storage; Virulent

\section{Introduction}

Groundnut (Arachis hypogaea L.) is a leguminous plant which belongs to the family Fabaceae. The crop is grown both in the tropical and Sub-tropical areas [1] and have high nutritional and economic importance as well as a source of edible oil $[2,3]$. Total world production of groundnut is about 26.4 million hectares in more than 100 countries with estimated mean yield of 1.4 tons per hectare [4]. Ntare BR, et al. [4] reported that developing countries account for $97 \%$ of total area of production with a $94 \%$ overall yield of this oil crop. Major producers of groundnut are China and India with over $60 \%$ of the world total yield [2]. Africa is the second largest producer with about $25 \%$ of total world yield coming 


\section{Open Access Journal of Mycology \& Mycological Sciences}

mainly from Nigeria, Senegal and Sudan [5]. Groundnut is one of the world's most important oilseed crops [6], ranking as the 4th most important oilseed crop of the world and the 13th most important food crop [7].

In spite of the large quantity of groundnut production, diseases continue unabated reducing yield of the crop considerably. Pathogens such as fungi, bacteria, viruses, nematodes are the leading causes of diseases but rot diseases are mostly fungal diseases which are either soil or seed borne [8]. The production of groundnut is constrained by Aspergillus species of fungi, which cause yield losses and produce highly toxic and carcinogenic chemical substances known as aflatoxins [9]. Verma SS, et al. [10] reported that, the action of these fungi resulted to loss of seeds, fruits, grains, vegetables and other plant products during picking, transit and storage rendering them unhealthy for human consumption even by producing mycotoxins and also reduce the total nutritive value. Production of aflatoxin is associated with spore production by species of Aspergillus Calvo AM, et al. [11]. The most commonly recognized aflatoxigenic fungi are A. parasiticus, A. flavus, A. nomius. A. niger. Other fungi reported to produce aflatoxins are Aspergillus bombycis, A. ochraceus, A. tamarii and A. pseudotamari [12]. A. flavus and $A$. fumigatus have also been identified as pathogenic to animals and humans [13].

Seed borne fungi are generally controlled by application of synthetic pesticides which are often considered to be both efficient and effective [14]. Groundnut is one of the most susceptible crops to aflatoxin contamination yet it is a major staple, widely cultivated and consumed in the world [15]. Aflatoxin contamination also causes economic losses of corn, cottonseed, Sorghum, wheat, rice and other commodities, and economic losses of processed food and feedstuffs. Aflatoxins are endangering human health, animal production and countries economy [16]. The continuous use of these synthetic fungicides has serious environmental issues such as non-biodegradability, residual toxicological and environmental problems [17-19], hence the need for alternative safer means of control. The use of plants and their by-products have shown to contained pests and diseases control properties $[20,21]$. These plant products contained variables of secondary metabolites such as alkaloids, tannins, flavonoilds, terpenoids and so many others with different levels of antimicrobial properties [22]. A lot of these botanical substances degrade more quickly within few hours or days compared to the non-degradable chemical compounds, safe, cheap, easily available and environmentally friendly and have often times been used successfully in the management of crop diseases [23,24].

The aim of this study is to determine the inhibitory effect of seed extracts of Moringa oleifera and rhizomes of Zingiber officinale in the control of postharvest aflatoxigenic fungi rot of groundnut seeds and hence reduce rot and increase postharvest shelf life.

\section{Materials and Methods}

\section{Study Area}

The experiment was conducted in the Microbiology Laboratory, Federal University Dutsin-Ma, Katsina State, Nigeria between March and July, 2019.

\section{Collection of Seed Samples}

Samples of rotted groundnut seeds were collected from farmers stores in three Local Government areas of Katsina State namely: Dutsin-Ma, Kurfi and Safana at two month interval for three times between March, 2019 and July, 2019. Samples were packaged in different polythene bags at the rate of thirty two (32) seeds from each of the 3 locations and were taken to Microbiology Laboratory, Federal University DutsinMa for isolation and identification of fungi organisms. Potato Dextrose Agar (PDA) was used as the medium for growth of the pathogens which was prepared based on manufacturer's recommendation. Pathogenicity test was carried out using the healthy groundnut seed obtained from farmers' barns.

\section{Isolation and Identification of Fungi from Rotted Groundnut Seeds}

Rotted groundnut seeds were collected and washed in clean running tap water. Seeds were cut into small sizes under aseptic condition from the advancing edge of lesion using sterile scalpel. Pieces were surface sterilized in $5 \%$ Sodium hypochlorite solution for 1 minute before they were rinsed in four successive changes of sterile distilled water and were dried on sterile filter paper for 2 minutes $[25,26]$. The pieces of the dried groundnut tissues were plated in sterile solidified Potato Dextrose Agar (PDA) plates. Plates were incubated for 7 days at ambient room temperature $\left(28 \pm 5^{\circ} \mathrm{C}\right)$ to observe growths and for the development of fungi mycelial. Sub-culture was done in order to obtain pure cultures of fungi mycelial after 7 days of incubation [25]. Morphology and culture characteristics of fungi obtained as well as the aid of compound microscope were used in identification of the fungi and this was compared with already established literatures $[27,28]$.

\section{Determination of the Frequency of Occurrence of the Isolates}

Frequencies of occurrence of the isolates from rotted groundnut seeds were determined based on the number of fungi isolated at different times from the different locations. 


\section{Open Access Journal of Mycology \& Mycological Sciences}

Fungi organisms were isolated at monthly interval and their frequencies were expressed based on the number of times each fungus was isolated in a month. This was expressed as a percentage of the total of all the different fungi isolated as described in this equation.

$$
\% \text { frequency of occurrence }=\frac{p}{q} \times \frac{100}{1}
$$

Where;

$p=$ number of times a fungal isolate was encountered over the period

$q=$ total number of fungal isolates over the period

Stock cultures of the isolated pathogens were maintained on slant of acidified potato dextrose agar (PDA) in McCartney bottles for pathogenicity test.

\section{Pathogenicity Test}

Five pathogens (Aspergillus niger, A. flavus, A. ochraceus, Fusarium oxysporum, and Mucor $s p$ ) were tested for their ability to illicit rot apparently healthy looking groundnut seeds. Healthy looking seeds were washed in running tap water before surface sterilizing them with $5 \%$ Sodium hypochlorite solution for 30 seconds and were rinsed in four successive changes of sterile distilled water and dried for 2 minutes. Holes were removed from each of the seeds with a $2 \mathrm{~mm}$ diameter flame-sterilized needle and thereafter aseptically inoculated with a $2 \mathrm{~mm}$ diameter disc of a 5-day old culture of the isolated fungal cultures. The holes on the inoculated groundnut seeds were sealed with petroleum jelly to avoid infection by airborne pathogenic organisms $[26,29]$ before incubating them at ambient room temperature $\left(28 \pm 5^{\circ} \mathrm{C}\right)$. The groundnut seeds without fungi inoculum inoculated with solidified potato dextrose agar serve as control. Each of the treatment including control experiment was replicated three times before incubating for 10 days in three replicates each. Each of the fungus tested was reisolated from the diseased groundnut seeds and cultured on sterile PDA plates. Rot symptoms produced on the reinoculated PDA plates were compared with the symptoms of the naturally infected groundnut seeds. The pathogens were re-isolated and identified using the same procedures described earlier. Disease symptoms produced by artificial inoculation of the groundnut seeds with the pathogens after the incubation period were compared with those observed on the naturally infected pepper [26].

\section{Determination of Purity of Extract}

Purity of seed extract of Moringa oleifera and rhizome of Zingiber officinale were determined by streaking separately onto sterile plates of the test media (PDA). The mixture of PDA-extract were incubated at ambient room temperature $\left(28 \pm 5^{\circ} \mathrm{C}\right)$ for 24 hours [25] and were observed for possible growth of contaminants and the absence of any growth confirmed the purity of the test extracts.

\section{Preparation of Plant Extract}

Seed extract of Moringa oleifera and rhizome of Zingiber officinale were evaluated against mycelial growth of $A$. flavus and $A$. niger. The plant materials were thoroughly washed in running tap water, air-dried and separately ground into fine powder using pestle and mortar. $40 \mathrm{~g}, 80 \mathrm{~g}$ and $120 \mathrm{~g}$ of powdered moringa seeds ginger rhizomes were each mixed with $1 \mathrm{~L}$ of boiled water to give a concentration of 40 $\mathrm{g} / \mathrm{L}, 80 \mathrm{~g} / \mathrm{L}$ and $120 \mathrm{~g} / \mathrm{L}$ of the moringa and ginger extracts respectively. The mixtures were vigorously agitated and left to settle for 24 hours, after which they were filtered through four layers of muslin cloth. Five milliliters each of the prepared plant extracts at different concentrations was used to amend $15 \mathrm{~mL}$ of Potato Dextrose Agar (PDA) before inoculation of the test fungi. The antifungal potency of moringa and ginger were compared at different concentrations to test their inhibitory effect on mycelial growth of A. flavus and A. niger in vitro.

\section{Antifungal Efficacy of Plant Extracts on Fungal Growth}

Efficacy of M. oleifera and Z. officinale were tested against $A$. flavus and $A$. niger which were the two most virulent pathogens responsible for aflatoxigenic contamination of groundnut seeds using the method of Two perpendicular lines were drawn at the bottom of the plates to create four equal sections [30]. Five milliliters of each plant extract at different levels of concentrations was poured into the sterilized Petri dishes containing $15 \mathrm{ml}$ of the prepared PDA medium [31], the mixture was allowed to solidify. The plates were then inoculated at the centre where the two lines intercepted with disc $5 \mathrm{~mm}$ diameter of a 7 day old culture of the test fungi as described by Vedashree S, et al. [32]. Each of the treatment was replicated three times for each of the concentrations. The procedure was same for the control experiment except that $5 \mathrm{ml}$ of sterile distilled water was added to PDA instead of plant extracts respectively; the treatments and control were completely randomized [33] and incubated for seven days at ambient room temperature $\left(28 \pm 5^{\circ} \mathrm{C}\right)$.

\section{Measurement of Mycelial Growth of $A$. flavus and $A$. niger}

Mycelial growth of $A$. flavus and A. niger were measured daily for five consecutive days using a transparent ruler. The absence of growth in any of the plates was an indication of the efficacy of moringa and ginger. The efficacy of the two extracts was determined by measuring percent growth 
inhibition (PGI) of the pathogens in both the amended plates and the control plates as described by Korsten L, et al. [34].

$$
P G I(\%)=\frac{R-R_{1}}{R} \times 100
$$

Where,

PGI = Percentage Growth Inhibition;

$\mathrm{R}=$ the distance of fungal growth (measured in $\mathrm{mm}$ ) from the point of inoculation to the colony margin in control plate; $\mathrm{R}_{1}=$ the distance of fungal growth from the point of inoculation to the colony margin in treated plate.

\section{Data Analysis}

Data was analyzed by one-way analysis of variance (ANOVA) according to [33]. Two-tailed paired Student's t-test and Least Significant Difference (LSD) according to [35] were used to separate the means that were significantly different at $P \leq 0.05$.

\section{Results}

\section{Isolation and Identification Fungi from Groundnut Seeds}

Fungi pathogens identified from the rotted groundnut seeds in the locations which are associated with causing aflatoxin contamination of groundnut are A. niger, A. flavus, A. ochraceus, A.tamarii, A. parasitica. Other fungi identified include F. oxysporum, Mucor sp, Rhizotonia sp. The cultures of $A$. flavus and $A$. ochraceus are presented in Plate 1 and Plate 2 , respectively.

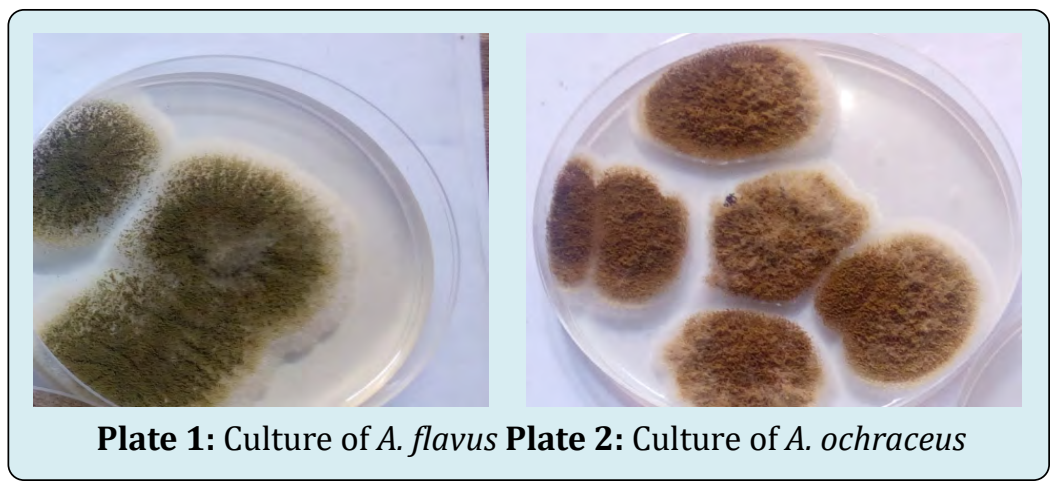

\section{Frequency of Occurrence and Percentage of Fungi Pathogens}

Figure 1 shows frequency of fungi isolated in the various locations between March and July, 2019 while Tables 1-9 present the frequencies and percentages of the fungi isolated from Dutsin-ma, Kurfi and Safana local Government areas of Katsina State, respectively. The isolated and identified fungi pathogen are A. niger, A. flavus, A.tamarii, A. parasitica, A. ochraceous. Other identified pathogens include Mucor sp, F. oxysporium and Rhizotonia sp. Among the Aflatoxin causing pathogens identified; $A$. niger was the most occurring in both March, May and July and also in all the locations. Mucor only appeared in July at $5.36 \%$ in Dutsin-ma and $18.18 \%$ in Kurfi. Rhozotonia spp appeared only once in March at 5.7\% in Dutsin-Ma.

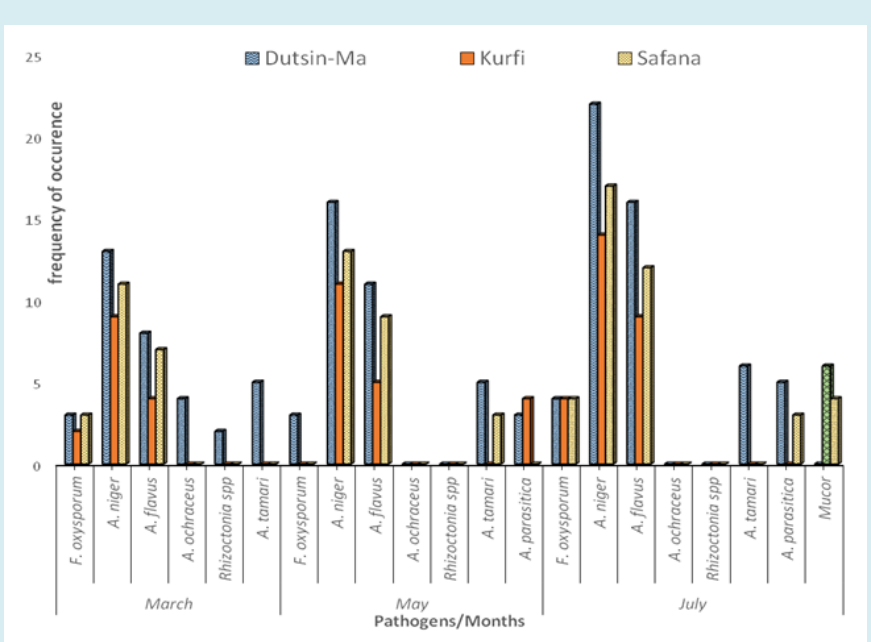

Figure 1: Frequency of occurrence of fungal pathogens at different locations between March and July, 2019. 


\section{Pathogenicity Test}

Pathogenicity test was carried out on A. niger, A. flavus, F. oxysporum, rhizoctonia sp and Mucor sp isolated from groundnut seed collected from storage in Dutsin-ma, Kurfi and Safana. A. niger and A. flavus exhibited high level of virulence compared with $F$ oxysporum and rhizoctonia sp within the ten days of inoculation. Rot symptoms and mycelial growth were apparently visible on the groundnut seeds from the fouth day of inoculation. Seeds inoculated without fungi showed no sign of rot. M. oleifera and Z. officinale extracts were used to inhibit the growth of $A$. niger and A. flavus that showed high level of rot.

\section{Percentage frequency of occurrence of fungi in Dutsin-Ma, Kurfi and Safana in March}

Table 1 shows the frequency of occurrence and percentage of pathogens in Dutsin-ma, Kurfi and Safana in the month of March. Among the pathogens isolated, A. niger and $A$. flavus were found to be the most frequent fungi in the locations in March.

\begin{tabular}{|c|c|c|c|}
\hline Locations & Fungi & Frequency of Fungi Occurrence & \% Frequency of Occurrence \\
\hline \multirow{4}{*}{ Dutsin-m $\boldsymbol{A}}$. & F. oxysporum & 3 & 8.57 \\
\cline { 2 - 4 } & A. niger & 13 & 37.14 \\
\cline { 2 - 4 } & A. flavus & 8 & 22.86 \\
\cline { 2 - 4 } & A. ochraceous & 4 & 11.46 \\
\cline { 2 - 4 } & Rhizoctonia spp & 2 & 5.71 \\
\cline { 2 - 4 } & A. tamarii & 5 & 14.31 \\
\hline \multirow{4}{*}{ Kurfi } & TOTAL & $\mathbf{3 5}$ & $\mathbf{1 0 0}$ \\
\cline { 2 - 4 } & F. oxysporum & 2 & 13.33 \\
\cline { 2 - 4 } & A. niger & 9 & 60 \\
\cline { 2 - 4 } & A. flavus & 4 & 26.66 \\
\hline \multirow{4}{*}{ Safana } & TOTAL & 15 & $\mathbf{1 0 0}$ \\
\cline { 2 - 4 } & F. oxysporum & 3 & 14.29 \\
\cline { 2 - 4 } & A.niger & 11 & 52.38 \\
\cline { 2 - 4 } & A. flavus & 7 & 33.33 \\
\cline { 2 - 4 } & TOTAL & 21 & $\mathbf{1 0 0}$ \\
\hline
\end{tabular}

Table 1: Percentage frequency of fungi pathogens from Dutsin-Ma in March, 2019.

\section{Percentage frequency of occurrence of fungi in Dutsin-Ma, Kurfi and Safana in May}

Table 2 shows result of fungi and their percentages at
Dutsin-Ma, Kurfi and Safana in May. Result revealed that $A$. niger and A. flavus are the most frequently occurring fungi.

\begin{tabular}{|c|c|c|c|}
\hline Locations & Fungi & Frequency of Fungi Occurrence & \% Frequency of Occurrence \\
\hline \multirow{4}{*}{ Dutsin-Ma } & F. oxysporum & 3 & 7.89 \\
\cline { 2 - 4 } & A. niger & 16 & 42.10 \\
\cline { 2 - 4 } & A. flavus & 11 & 28.94 \\
\cline { 2 - 4 } & A. parasitica & 3 & 7.89 \\
\cline { 2 - 4 } & A. tamarii & 5 & 13.15 \\
\cline { 2 - 4 } & TOTAL & $\mathbf{3 8}$ & $\mathbf{1 0 0}$ \\
\hline
\end{tabular}




\section{Open Access Journal of Mycology \& Mycological Sciences}

\begin{tabular}{|c|c|c|c|}
\hline \multirow{4}{*}{ Kurfi } & A. flavus & 5 & 25 \\
\cline { 2 - 4 } & A. niger & 11 & 55 \\
\cline { 2 - 4 } & A. parasitica & 4 & $\mathbf{1 0 0}$ \\
\cline { 2 - 4 } & TOTAL & $\mathbf{2 0}$ & 52 \\
\hline \multirow{4}{*}{ Safana } & A.niger & 13 & 36 \\
\cline { 2 - 4 } & A. flavus & 9 & 12 \\
\cline { 2 - 4 } & A. tamari & 3 & $\mathbf{1 0 0}$ \\
\cline { 2 - 4 } & TOTAL & $\mathbf{2 5}$ & 20 \\
\hline
\end{tabular}

Table 2: Frequency percentage of fungi pathogens from Dutsin-Ma in May, 2019.

Percentage frequency of fungi from Dutsin-Ma, Kurfi and Safana in July

Table 3 shows percentage of fungi and their frequency of isolation from Dutsin-Ma, Kurfi and Safana in July. A. niger and A. flavus are the highest occurring fungi in all the locations.

\begin{tabular}{|c|c|c|c|}
\hline Locations & Fungi & Frequency of Fungi Occurrence & $\%$ Frequency of Occurrence \\
\hline \multirow{7}{*}{ Dutsin-Ma } & F. oxysporum & 4 & 7.14 \\
\hline & A. niger & 22 & 39.28 \\
\hline & A. flavus & 16 & 28.57 \\
\hline & Mucor & 3 & 5.36 \\
\hline & A. parasitica & 5 & 8.92 \\
\hline & A. tamarii & 6 & 10.71 \\
\hline & TOTAL & 56 & 100 \\
\hline \multirow{5}{*}{ Kurfi } & F. oxysporum & 4 & 12.12 \\
\hline & A. niger & 14 & 42.42 \\
\hline & A. parasitica & 6 & 18.18 \\
\hline & Mucor & 9 & 27.2 \\
\hline & TOTAL & 33 & 100 \\
\hline \multirow{6}{*}{ Safana } & F. oxysporum & 4 & 10 \\
\hline & A.niger & 17 & 42.5 \\
\hline & A. flavus & 12 & 30 \\
\hline & A. parasitica & 3 & 7.5 \\
\hline & Mucor & 4 & 10 \\
\hline & TOTAL & 40 & 100 \\
\hline
\end{tabular}

Table 3: Percentage frequency of fungi pathogens from Dutsin-Ma in July, 2019.

Effect of different concentrations of $M$. oleifera and $Z$. Officinale on percentage growth inhibition of $A$. niger and $A$. flavus

The result presented in Table 4 shows the percentage inhibition of $A$. niger with $M$. oleifera and Z. officinale. At $40 \mathrm{~g} / \mathrm{L} M$. oleifera inhibited the growth of $A$. niger to a percentage of $59.79 \%$ compared to $Z$. officinale which inhibited to $60.32 \%$ with no significant difference $(P<0.05)$, while at $80 \mathrm{~g} / \mathrm{L}$ both $M$. oleifera and Z. officinale inhibited the growth of $A$. niger by $74.05 \%$ with no significant difference. While at $120 \mathrm{~g} / \mathrm{L}$ M. oleifera inhibited growth of $A$. niger by $73 \%$ compared to Z. officinale which inhibited by $87.33 \%$ with a significant difference between the extracts. The result presented in Table 1 shows the growth inhibition of $A$. flavus with M. oleifera and $Z$. oficinale, both extracts are potent in 


\section{Open Access Journal of Mycology \& Mycological Sciences}

the control of $A$. flavus. M. oleifera inhibited by $60.79 \%$ and $Z$. oficinale by $60.52 \%$ at $40 \mathrm{~g} / \mathrm{L}$ with no significant difference, while at $80 \mathrm{~g} / \mathrm{l} \mathrm{M}$. oleifera did better by inhibiting growth of A. flavus by $62.47 \%$ compare to $Z$. officinale which inhibited by $60.94 \%$. At concentration of $120 \mathrm{~g} / \mathrm{L}$. M. oleifera inhibited the pathogen growth by $60.80 \%$ while Z. officinale inhibited growth by $61.13 \%$. There was however, no significant difference between concentrations in the extracts.

\begin{tabular}{|c|c|c|c|c|}
\hline \multirow{2}{*}{ Pathogen/ Conc } & \multicolumn{2}{|c|}{ Extract } & \multirow{2}{*}{ T-Value } & \multirow{2}{*}{ P-Value } \\
\cline { 2 - 4 } & M. oleifera & Z. officianale & & \\
\hline A. niger & & & 0.15 & 0.88 \\
\hline $40 \mathrm{~g} / \mathrm{L}$ & $59.79 \pm 4.97$ & $60.32 \pm 3.33$ & 0 & 1 \\
\hline $80 \mathrm{~g} / \mathrm{L}$ & $74.05 \pm 0.45$ & $74.05 \pm 0.45$ & 3.32 & $0.04^{*}$ \\
\hline $120 \mathrm{~g} / \mathrm{L}$ & $73.53 \pm 5.63$ & $87.33 \pm 4.49$ & & 0.91 \\
\hline $\boldsymbol{A}$ flavus & & & 0.12 & 0.34 \\
\hline $40 \mathrm{~g} / \mathrm{L}$ & $60.79 \pm 1.81$ & $60.52 \pm 2.45$ & 1.22 & 0.9 \\
\hline $80 \mathrm{~g} / \mathrm{L}$ & $62.47 \pm 0.58$ & $60.94 \pm 2.10$ & 0.13 & \\
\hline $120 \mathrm{~g} / \mathrm{L}$ & $60.80 \pm 2.06$ & $61.13 \pm 0.13$ & & \\
\hline
\end{tabular}

* shows statistical significant at $P<0.05$

Table 4: Effect of different concentrations of M. oleifera and Z. officinale on percentage growth inhibition of $A$. niger and $A$. flavus.

Variations between concentration of $M$. oleifera and Z. officinale on percentage growth inhibition of $A$. niger and $A$. flavus

Variations in concentration of plant extracts presented in Table 5 on the control of mycelial growth of $A$. niger and A. flavus reveal that percentage growth inhibition of 59.79 $\%$ at $40 \mathrm{~g} / \mathrm{L}$ differed significantly from $74.05 \%$ at $80 \mathrm{~g} / \mathrm{L}$ and $73.53 \%$ at $120 \mathrm{~g} / \mathrm{L}$. In control of $A$. flavus with $M$. oleifera, $40 \mathrm{~g} / \mathrm{L}(60.79 \%)$ was not significantly different from 80 $\mathrm{g} / \mathrm{L}(62.47 \%)$ and $120 \mathrm{~g} / \mathrm{L}(60.88 \%)$. Variation of the concentration on Table 2 from extract of $Z$. officinale in the control of $A$. niger shows that at $40 \mathrm{~g} / \mathrm{L}, 80 \mathrm{~g} / \mathrm{L}$ and 120 $\mathrm{g} / \mathrm{L}$ produced a significant difference in the concentrations. Concentrations of $40 \mathrm{~g} / \mathrm{L}, 80 \mathrm{~g} / \mathrm{L}$ and $120 \mathrm{~g} / \mathrm{L}$ of $Z$. officinale on the control of $A$ flavus shows no significant difference from one another. At $40 \mathrm{~g} / \mathrm{L}$, the percentage growth inhibition of $60.57 \%$ was not significant different in the management of mycelial growth of $A$. flavus from $80 \mathrm{~g} / \mathrm{L}$ at $60.94 \%$ and $120 \mathrm{~g} / \mathrm{L}$ at $61.13 \%$.

\begin{tabular}{|c|c|c|}
\hline \multirow{2}{*}{ Conc. /ncubation Period } & \multicolumn{2}{|c|}{ Extract } \\
\cline { 2 - 3 } & A. niger & A. flavus \\
\hline M. oleifera & & $60.79 \pm 1.05$ \\
\hline $40 \mathrm{~g} / \mathrm{L}$ & $59.79 \pm 2.87^{\mathrm{b}}$ & $62.47 \pm 0.33$ \\
\hline $80 \mathrm{~g} / \mathrm{L}$ & $74.05 \pm 0.26^{\mathrm{a}}$ & $60.88 \pm 0.33$ \\
\hline $120 \mathrm{~g} / \mathrm{L}$ & $73.53 \pm 3.25^{\mathrm{a}}$ & $0.41 \mathrm{~ns}$ \\
\hline$P$-Value & 0.01 & $60.57 \pm 1.41$ \\
\hline Z. officianale & & $60.94 \pm 1.21$ \\
\hline $40 \mathrm{~g} / \mathrm{L}$ & $60.32 \pm 1.92^{\mathrm{c}}$ & $61.13 \pm 1.45$ \\
\hline $80 \mathrm{~g} / \mathrm{L}$ & $74.05 \pm 0.26^{\mathrm{b}}$ & $0.95 \mathrm{~ns}$ \\
\hline $120 \mathrm{~g} / \mathrm{L}$ & $87.33 \pm 2.59^{\mathrm{a}}$ & \\
\hline$P$-Value & $<0.01$ & \\
\hline
\end{tabular}

Means on the same column with different superscript are statistically significant $(\mathrm{P}<0.05)$, ns $=$ not significant.

Table 5: Variations between concentrations of $M$. oleifera and Z. officinale on percentage growth inhibition of $A$. niger and $A$. flavus. 


\section{Open Access Journal of Mycology \& Mycological Sciences}

\section{Discussion}

Fungi pathogens consistently isolated in large numbers and found to be associated with aflatoxin contamination of groundnut are $A$. flavus and $A$. niger. The isolation of these fungi in large numbers at different locations and different times in this area motivated the study to focus on their management using some plant extracts of antimicrobial importance [36,37]. This also confirms the consistent isolation and presence of Aspergillus spp from groundnut seeds from different locations as confirmed by Ihejirika GO, et al. [8], that Aspergillus spp were the prominent fungi isolated from stored groundnut seeds and are highly known to be the cause of aflatoxin contamination. Findings from this study revealed that $M$. Oleifera is potent in the control of $A$. niger and $A$. flavus as other studies have also shown that the fungicidal effect of Moringa extracts on some soil-borne fungi such as Rhizoctonia spp, Aspergellus spp, Pythium spp and Fusarium spp were recorded by many investigators [38]. Similarly, Mamkaa DP, et al. [36] reduced the mycelial growth of $A$. flavus and $B$. theobromae causing rot of cowpea seeds in storage with leaf extracts of $M$. oleifera and $V$. amygdalina. According to Amadioha AC, et al. [39]; Gwa VI, et al. [26]; Nwankiti AO, et al. [21] differences in efficacy of the extracts could be attributed to the quantity and quality of phytochemical compounds present in the extracts.

It was observed that the efficacy of the extracts increased along with increase in the concentration of the aqueous extracts which conforms to earlier findings by Nwankiti AO, et al. [21]; Ekefan EJ, et al. [40]; Gwa VI, et al. [41] observed that higher sample ratio to solvent was ideal in inhibiting mycelial growth of yam fungi pathogens both in vitro and in vivo. Our findings also revealed that $M$. oleifera and $Z$. officinale were more effective in the inhibition of $A$. niger than A. flavus. This may be due to high high concentration of flavonoids, terpenes, saponins, steroids, tannins, glycosides and coumarins in the two plant extracts against $A$. niger Qusti S, et al. [42]. Gwa VI, et al. [20] also observed high inhibition on the mycelial growth of $A$. niger in vitro isolated from yam tubers. The anti-fungal property of ginger in reducing the mycelial growth of fungal pathogens agreed with the result of Nwankiti AO, et al. [21] who reduced the growth of collectotrichum spp isolated from yam tubers with extract of Z. officinale, indicating that it is a potent extract for control of fungi pathogens. The inhibition recorded on A. niger from $Z$. officinale was more than on M. oleifera. This is similar to the result obtained by Yeni IJ, et al. [43] who studied the antifungal properties of $Z$. officinale on A. flavus, A. niger, $F$. solani and $F$ oxysporum on post-harvest rot of water yam $(D$. alata) and revealed that the extract was effective against the growth of the fungi found out that the extract inhibited the growth of all the pathogens tested.

\section{Conclusion}

The study revealed that fungi such as $A$. niger, A. flavus, A. ochraceus, A. tamarii, A. parasitica, F. oxysporum, Mucor sp and Rhizotonia sp are common rot causing fungi of groundnut seeds in storage. Most of these pathogens such as $A$. niger, A. flavus, A. ochraceus, A. tamari and A. parasitica are responsile for aflatoxin contamination of groundnut seeds in storage. Extracts of M. oleifera and Z. officinale at different concentrations were found to be effective in inhibiting the growth of $A$. niger and $A$. flavus in vitro. It is therefore concluded and recommended that such extracts from M. oleifera and Z. officinale extracts are cheap, effective and environmentally friendly can be used to reduce rot development in groundnut seed and increase its shelf life.

\section{Conflict of Interest Disclosure}

The authors declare that there is no conflict of interest regarding the publication of this paper.

\section{Funding Acknowledgement}

This research received no specific grant from any funding agency.

\section{References}

1. Shiyam JO (2010) Growth and yield response of groundnut (Arachis hypogaea L.) to plant densities and phosphorus on an Ultisol in Southeastern Nigeria. Libyan Agriculture Research Center Journal International 1(4): 211-214.

2. Noba $K$, Ngom A, Guèye $M$, Bassène $C$, Kane $M$, et al. (2014) Groundnuts in Senegal: state of play.

3. Spears JF, Jordan DL, Bailey JE (2002) Groundnut seed production-a guide for producers of Virginia-type groundnut seed. N. C. Coop. Ext Serv Bull AG 662: 1-7.

4. Ntare BR, Diallo AT, Ndjeunga J, Waliyar F (2008) Groundnut Seed production Manual. Int Crops Research Institute, India.

5. Kouadio AL (2007) Interuniversity students in natural risk management: Forecasting national peanut production in Senegal from the AMS agro-meteorological model and NDVI. ULG-Gembloux, pp: 54.

6. Dwivedi SL, Crouch JH, Nigam SN, Ferguson ME, Paterson AH (2003) Molecular breeding of groundnut for enhanced productivity and food security in the semiarid tropics: Opportunities and challenges. Advance in Agronomy 80: 153-221. 


\section{Open Access Journal of Mycology \& Mycological Sciences}

7. Surendranatha EC, Sudhakar C, Eswara NP (2011) Aflatoxin contamination in groundnut induced by aspergillus flavus type fungi: a critical review. Int J Appl Biol \& Pharm Tech 2(2): 180-192.

8. Ihejirika GO, Nwufo MI, Durugbo CI, Ibeawuchi II, Onyia VH, et al. (2005) Identification of Fungi Associated with Storage Rot of Groundnut in ImoState South Eastern Nigeria. Plant Pathology Journal 4(2): 110-112.

9. Ajeigbe HA, Waliyar F, Echekwu CA, Ayuba K, Motagi BN, et al. (2014) A Farmer's Guide to Groundnut Production in Nigeria.

10. Verma SS, Tomer RPS, Verma U (2003) Loss of viability and vigour in Indian mustard seeds stored under ambient conditions. Seed Research 31: 90-93.

11. Calvo AM, Wilson RA, Bok JW, Keller NP (2002) Relationship between secondary metabolism and fungal development. Microbiol Mol Biol Rev66: 447-459.

12. Mishra HN, Das C (2003) A review on biological control and metabolism of aflatoxin. Crit Rev Food Sci Nutr 43(3): 245-264.

13. Pepeljnjak S, Slobodnjak Z, Šegvić M, Peraica M, Pavlović M (2004) The ability of fungal isolates from human lung aspergilloma to produce mycotoxins. Hum Exp Toxicol 23(1): 15-19.

14. Ahmed Z, Raziq F, Khan H, Idress M (2012) Chemical and Biological Control of Fusarium Root Rot of Okra. Pakistan Journal of Botany 44(1): 453-457.

15. Guchi E (2015) Aflatoxin Contamination in Groundnut (Arachis hypogaea L.) Caused by Aspergillus Species in Ethiopia. Journal of Applied \& Environmental Microbiology 3(1): 11-19.

16. (2006) Mycotoxins in African foods: Implications to food safety and health (AFRO Food safety (FOS). World Health Organization.

17. Ijato JY, Otoide JE, Ijadunola JA, Aladejimokun AO (2011) Efficacy of antimicrobial effect of Vernonia amygdalina and Tridax procumbens in vitro control of tomato (Lycopersicum esculentum) post harvest fruit rot. Report and Opinion 3(1): 120-123.

18. Nsabiyera V, Ochwo-ssemakula M, Sseruwagi P (2012) Hot pepper reaction to field diseases. African Crop Science Journal 20(1): 77-97.

19. Malkhan SG, Shahid A, Masood A, Kangabam SS (2012) Efficacy of plant extracts in plant disease management. J Earth Envir Sci 3(3): 425-433.
20. Gwa VI, Ekefan EJ (2018) Fungicidal Effect of Some Plant Extracts against Tuber Dry Rot of White Yam (Dioscorea rotundata Poir) Caused by Aspergillus Niger. Int J Hort Agric 3(3): 1-7.

21. Gwa VI, Nwankiti AO (2018) In vitro and In vivo antimicrobial potency of selected plant extracts in the control of postharvest rot-causing pathogens of yam tubers in storage. Global Journal of Pests, Diseases and Crop Protection 6(1): 276-287.

22. Aidah N, Abdullah N, Oskoueian E, Sieo CC, Saad WZ (2014) Membrane-active antibacterial compounds in methanolic extracts of Jatropha curcas and their mode of action against Staphylococcus aureus S1434 and Escherichia coli E216. Int J Agric Biol 16: 723-730.

23. Riaz T, Khan SN, Javaid A (2010) Management of cormrot disease of gladiolus by plant extracts. Nat Prod Res 24(12): 1131-1138.

24. Gwa VI, Nwankiti AO, Hamzat OTH (2018a) Antimicrobial activity of five plant extracts and synthetic fungicide in the management of postharvest pathogens of yam (Dioscorea rotundata Poir) in storage. Acad J Agric Res 6(6): 165-175.

25. Gwa VI, Nwankiti AO (2017) In Vitro Antagonistic Potential of Trichoderma harzianum for Biological Control of Fusarium moniliforme isolated from Dioscorea rotundata Tubers. Virol-mycol 6(2): 1-8.

26. Gwa VI, Richard IB (2018) Susceptibility of White Yam (Dioscorea rotundata Poir) Tuber to Rot Fungi and Control with Extracts of Zingiber officinale Rosc. Azadirachta indica A. Juss. and Piper guineense Schumach. J Plant Pathol Microbiol 9: 452.

27. Navi SS, Bandyopadhyay R, Hall AJ, Bramel-Cox PJ (1999) A pictorial Guide for the Identification of Mold Fungi on Sorghum Grain. International Crops Research Institute for the Semi-Arid Tropics, pp: 118.

28. Agrios GN (2005) Plant Pathology. Academic Press, New York.

29. Gwa VI, Ekefan EJ, Nwankiti AO (2017) Antifungal Potency of Some Plant Extracts in the Control of White Yam (Dioscorea rotundata poir) Tuber Rot. Adv Biotech \& Micro 7(1): 555703.

30. Amadioha AC, Obi VI (1999) Control of anthracnose disease of cowpea Cymbopogon citratus and Ocimum gratissimum. Acta phytopathol Entomol Hungerica 34(92): 85-89.

31. Nene ZH, Thapilyal, (2002) Management of mushroom 
pathogens through botanicals. Ind Phytopathol. 58(2): 189-193.

32. Vedashree S, Sateesh MK, Lakshmeesha TR, Sofi MS, Vedamurthy AB (2013) Screening and assay of extracellular enzymes in Phomopsis azadirachtae causing die-back disease of neem. J Agricultural Technol 9(4): 915-927.

33. Gomez KA, Gomez AA (1984) Statistical Procedures for Agricultural Research. $2^{\text {nd }}($ Edn.), John Wiley and sons, pp: 680 .

34. Korsten L, De Jager ES (1995) Mode of action of Bacillus subtillus for control of Avocado post-harvest pathogens. South African Avocado Growers Association yearbook 18: 124-130.

35. Cochran GW, Cox GM (1992) Experimental Designs. $2^{\text {nd }}$ (Edn.), John willey and Sons Inc, pp: 611.

36. Mamkaa DP, Gwa VI (2018) Effect of Moringa oleifera and Vernonia amygdalina Leaf Extracts against Aspergillus flavus and Botryodiplodia theobromae Causing Rot of Cowpea (Vigna unguiculata (L.) Walp) Seeds. Appl Sci Res Rev 5 (1-2): 1-7.

37. Sani S, Gwa VI (2018) Fungicidal Effect of Azadiracta Indica and Zingiber Officinale Extracts in the Control of Fusarium oxysporum and Rhizoctonia Solani on Tomato (Solanum Lycopersicum) Fruits. Innovative Techniques in Agriculture 2(4): 439-448.

38. Moyo B, Masika PJ, Muchenje V (2012) Antimicrobial activities of Moringa oleifera Lam leaf extracts. African Journal of Biotechnology 11(11): 2797-2802.

39. Amadioha AC (2003) Evaluation of some Plants Leaf Extracts against Colletotrichum lindemuthianum in Cowpea. Acta Phytopathologia et Entomologica Hungarica 32(2): 141-149.

40. Ekefan EJ, Nwankiti AO, Gwa VI (2018) Comparative Assessment of Antimicrobial Potency of Some Selected Plant Extracts against Seed Borne Pathogens o f Germinating Yam Setts. Journal Plant plant Microbioly 9: 444.

41. Gwa VI, Nwankiti AO, Ekefan, E J (2018b) Antifungal Effect of Five Aqueous Plant Extracts on Mycelial Growth of Penicillium expansum isolated from Rotted $\mathrm{Y}$ a $\mathrm{m}$ Tubers in Storage. Acta Scientific Agriculture 26: 65-70.

42. Qusti S, khatwa ANA, Lahwa, MA (2010) Screening of antioxidant activity and phenolic content of selected food items cited in the holly quran. Eur J Biol Sci 2: 40-51.

43. Yeni IJ (2011) Evaluation of Antifungal Effects of Extracts of Allium sativum and Nicotiana tabacum against Soft Rot of Yam (Dioscorea alata). Journal of Agricultural Research 3: 1-5. 